\title{
Assessing Lysine Requirement of Growing Chicken by Direct Comparison between Supplementation Technique and "Goettingen Approach"
}

\author{
Samadi ${ }^{1,2}$, Christian Wecke ${ }^{1}$, Anja Pastor ${ }^{1,3}$, Frank Liebert ${ }^{1}$ \\ ${ }^{1}$ Department of Animal Sciences, Division Animal Nutrition Physiology, Georg-August-University of Goettingen, \\ Goettingen, Germany \\ ${ }^{2}$ Animal Husbandry Department, Agricultural Faculty, Syiah Kuala University, Banda Aceh, Indonesia \\ ${ }^{3}$ Phytobiotics Futterzusatzstoffe GmbH, Eltville, Germany \\ Email: flieber@gwdg.de
}

How to cite this paper: Samadi, Wecke, C., Pastor, A. and Liebert, F. (2017) Assessing Lysine Requirement of Growing Chicken by Direct Comparison between Supplementation Technique and "Goettingen Approach". Open Journal of Animal Sciences, 7, 56-69.

http://dx.doi.org/10.4236/ojas.2017.71006

Received: November 24, 2016

Accepted: January 13, 2017

Published: January 16, 2017

Copyright $\odot 2017$ by authors and Scientific Research Publishing Inc. This work is licensed under the Creative Commons Attribution International License (CC BY 4.0).

http://creativecommons.org/licenses/by/4.0/ (c) (†) Open Access

\begin{abstract}
Validated procedures play an important role to obtain accurate information about individual amino acid requirement data. The aim of the present study was to assess lysine (Lys) requirement of growing chicken both by classical supplementation technique and principles of diet dilution technique as applied with "Goettingen approach". During the starter period ( $1-21 \mathrm{~d})$, a growth study with male meat type chicken (Ross 308) was conducted making use of five graded dietary Lys-levels (3 repetition boxes with $3 \mathrm{birds} / \mathrm{box})$. L-Lys $\cdot \mathrm{HCl}$ was gradually added to a diet based on wheat, soybean protein concentrate, wheat gluten and fishmeal to yield $80 \%, 87.5 \%$, 95\%, 102.5\% and $110 \%$ of the expected requirement level (13 g Lys/kg as fed). Diets were iso-energetic (12.8 MJME/kg) and iso-nitrogenous (21.65\% crude protein). Birds were fed on free choice level also to assess the feed intake (FI) effects as important factor on traditional response criteria. Analyzed body composition at start and end of the growth study yielded $\mathrm{N}$ deposition (ND) data for further data assessment using exponential approximations depending on dietary Lys content or observed Lys intake. The results indicated significant differences $(p<0.05)$ in response on body weight gain (BWG) and observed dietary protein quality with unexpected consequences for the derived Lys requirement data. According to the independent variable (Lys in \% of diet versus daily Lys intake) and aimed level of daily ND, the needed in-feed content of Lys varied between $1.24 \%$ and 1.46\%. Application of the exponential modelling by "Goettingen approach" overcame these misleading conclusions by modelling the relationship between required Lys intake and observed response data (BWG, ND) taking also into account the expected real feed intake to formulate the needed in-feed concentration.
\end{abstract}

\section{Keywords}

Growing Chicken, Lysine Requirement, Supplementation Technique, 
Diet Dilution Technique, N Utilization Model, Amino Acid Efficiency

\section{Introduction}

Inaccurate formulation of dietary amino acid supply will impair protein utilization and increase the total nitrogen output to the environment. In consequence, validated protein evaluation systems are a "must be" for improved efficiency of protein conversion process to satisfy current needs both for management of resources and for sustainability of the process to convert feed into food protein for human nutrition.

Mathematical models and statistical methods of data analysis have been created to improve the procedure for assessment of individual amino acid (AA) requirement data [1]-[10]. Especially, dose-response studies by using graded AA supplementations and their effect on selected response criteria plotted via different regression equations were applied. The AA requirement was derived at the dietary concentration of the limiting AA which yielded the maximum response or a definite percentage (mostly 95\%) of the observed asymptote of the fitted non-linear function. Baker et al. [11] and Baker [12] discriminated between "subjective" and "objective" estimates of the required dietary AA concentration. The term "subjective estimate" was concluded from broken-line analysis. Deriving the first point at which the quadratic response curve intersected the plateau delivered from broken-line analysis was interpreted as "objective estimate". In addition, Wang and Fuller [13] utilized individual AA deletion from a complete diet for estimation of AA requirement based on an observed slope of the response criteria between diets.

Gebhardt [14] has introduced an exponential N utilization model for growing monograstic animals. This model has been further developed and applied in growing chicks [15]-[26], pigs [27]-[32] and fishes [33] [34] based on principles of the diet dilution technique. Actually, the procedure is known as "Goettingen approach" [10], assessing AA requirements depending on factors like age, daily protein deposition and efficiency of utilization of the limiting AA in the diet, and considering the targeted feed intake.

Lysine (Lys) is generally the second limiting amino acid after methionine and cystine (Met + Cys) in soybean-based mixed feeds for chicken [35] [36] and is generally applied as a reference AA for ideal AA balanced poultry diets [37]. In consequence, accurate estimates of quantitative Lys requirement data depending on genotype, gender, age period or body weight (BW) and targeted performance level are needed, also considering dietary Lys efficiency and real feed intake [10] [26].

The purpose of this study was a comparative evaluation of Lys requirement data of growing chicken based both on supplementation technique and principles of the diet dilution technique ("Goettingen approach").

\section{Materials and Methods}

The experiments were conducted at Division Animal Nutrition Physiology at the GeorgAugust-University of Goettingen and approved by the the Animal Welfare Committee of Lower Saxony, Germany. 


\subsection{Animals and Housing}

A total number of 45 male meat-type chickens (Ross 308) were obtained from a commercial hatchery and prepared for the experiment during starter period (1-21d). Birds were housed in wire floor cages with 3 birds per box $(1 \mathrm{~m} \times 1 \mathrm{~m} \times 0.5 \mathrm{~m})$ and 3 boxes per treatment. The cages were equipped with individual feeders and self-drinking system. Housing temperature was maintained at $32^{\circ} \mathrm{C}$ (day old chicken) and sub sequenly continuously decreased to $25^{\circ} \mathrm{C}$ up to the end of the experimental period. Humadity was maintained between $60 \%-70 \%$ and warm red light was provided for $24 \mathrm{~h}$ per day.

\subsection{Diets and Feeding}

Experimental diets (Table 1 and Table 2) were formulated to provide Lys as limiting factor for dietary protein quality. L-Lys. $\mathrm{HCl}$ was gradually added to yield the dietary Lys supply as needed for application of the supplementation technique according to $80 \%, 87.5 \%, 95 \%, 102.5 \%$ and $110 \%$ of the expected requirement level (13 g Lys per $\mathrm{kg}$ diet as fed). A feed optimization program was applied (Fumi for Windows 4, HYBRIMIN ${ }^{\circledR}$ Computer + Programme GmbH \& Co KG, Hessich Oldendorf, Germany). All diets were iso-energetic (12.7 MJ ME/kg as fed) and iso-nitrogenous (21.6\% crude protein (CP) as fed) based on $48.0 \%$ wheat, $6.8 \%$ soybean protein concentrate (SPC), $5.0 \%$ wheat gluten and $5.0 \%$ fishmeal. L-glutamic acid was applied to adjust the Ncontent in the diets. Experimental diets were fed as pellets (R.A. Lister Co. Ltd., Dursley, UK) with a diameter of $2 \mathrm{~mm}$. Vitamins and minerals were added to meet or exceed NRC [39] recommendations. In addition, all diets were supplemented with phytase (ZY Phytase 5.000, activity per g: 5000 FYT 6-phytase, EC 3. 1.3.26, Lohmann Animal Health, Cuxhaven, Germany) and xylanase (ZY 68, activity per g: 1000 FXU Endo-1,4$\beta$-xylanase, EC 3.2.1.8, Lohmann Animal Health, Cuxhaven, Germany).

\subsection{Sample Collection}

At the start of the experiment, three birds of one day old chicken were sampled for body analyses and further calculation of $\mathrm{N}$-deposition. Birds were weighed and randomly allotted to the experimental diets. The chicks were fed ad libitum to assess the feed intake effects which are an important factor of influencing on traditional response criteria. Feed supply was recorded daily and spilled feed was quantified for correction of daily feed intake. During the growth study, birds were individually weighted weekly. At the end of experiment, all birds were fasted for 24 hours and euthanized by carbon dioxide exposure. All samples were stored at $-20^{\circ} \mathrm{C}$ for further body nitrogen analysis.

\subsection{Laboratory Analysis}

Diets were analyzed for dry matter (DM), crude nutrients, starch and sugar according to the German VDLUFA standards [40]. The nitrogen content was quantified due to the DUMAS-method (Tru-Mac, LECO, Moenchengladbach, Germany) and crude protein (CP) was calculated by factor 6.25. AAs were analysed by ion-exchange chromatography (Biochrom 30, Onken Ltd., Gruendau, Germany) following acid hydrolysis 
Table 1. Composition of the experimental diets ( $\mathrm{g} / \mathrm{kg}$ as fed).

\begin{tabular}{|c|c|c|c|c|c|}
\hline \multirow[b]{2}{*}{ Item } & \multicolumn{5}{|c|}{$\operatorname{Diet}^{1}$} \\
\hline & $\begin{array}{c}\text { L1 } \\
(80 \%)\end{array}$ & $\begin{array}{c}\mathrm{L} 2 \\
(87.5 \%)\end{array}$ & $\begin{array}{c}\text { L3 } \\
(95 \%)\end{array}$ & $\begin{array}{c}\text { L4 } \\
(102.5 \%)\end{array}$ & $\begin{array}{c}\text { L5 } \\
(110 \%)\end{array}$ \\
\hline Wheat & 480.00 & 480.00 & 480.00 & 480.00 & 480.00 \\
\hline Wheat starch & 220.23 & 220.43 & 220.62 & 220.85 & 230.05 \\
\hline Soy protein concentrate & 60.75 & 60.75 & 60.75 & 60.75 & 60.75 \\
\hline Fish meal & 50.00 & 50.00 & 50.00 & 50.00 & 50.00 \\
\hline Wheat gluten & 50.00 & 50.00 & 50.00 & 50.00 & 50.00 \\
\hline Soybean oil & 20.97 & 20.85 & 20.73 & 20.58 & 20.45 \\
\hline DCP & 10.63 & 10.63 & 10.63 & 10.63 & 10.63 \\
\hline $\mathrm{CaCO}_{3}$ & 5.00 & 5.00 & 5.00 & 5.00 & 5.00 \\
\hline $\mathrm{NaCl}$ & 1.80 & 1.80 & 1.8 & 1.80 & 1.8 \\
\hline Premix $^{2}$ & 10.00 & 10.00 & 10.00 & 10.00 & 10.00 \\
\hline L-Glutamic acid & 34.60 & 32.60 & 30.60 & 38.6 & 36.60 \\
\hline L-Lysine $\cdot \mathrm{HCl}$ & 5.00 & 6.30 & 7.50 & 8.80 & 10.0 \\
\hline DL-Methionine & 4.50 & 4.50 & 4.50 & 4.50 & 4.50 \\
\hline L-Valine & 3.80 & 3.80 & 3.80 & 3.80 & 3.80 \\
\hline L-Threonine & 3.30 & 3.30 & 3.30 & 3.30 & 3.30 \\
\hline L-Tryptophan & 0.50 & 0.50 & 0.50 & 0.50 & 0.50 \\
\hline L-Arginine & 5.40 & 5.40 & 5.40 & 5.40 & 5.40 \\
\hline L-Isoleucine & 2.90 & 2.90 & 2.90 & 2.90 & 2.90 \\
\hline L-Leucine & 3.30 & 3.30 & 3.30 & 3.30 & 3.30 \\
\hline L-Phenylalanine & 2.60 & 2.60 & 2.60 & 2.60 & 2.60 \\
\hline L-Histidine & 0.90 & 0.90 & 0.90 & 0.90 & 0.90 \\
\hline Phytase $^{3}$ & 0.05 & 0.05 & 0.05 & 0.05 & 0.05 \\
\hline Xylanase $^{4}$ & 0.40 & 0.40 & 0.40 & 0.40 & 0.40 \\
\hline
\end{tabular}

${ }^{1} \mathrm{~L} 1=80 \%, \mathrm{~L} 2=87.5 \%, \mathrm{~L} 3=95 \%, \mathrm{~L} 4=102.5 \%, \mathrm{~L} 5=110 \%$ of the expected dietary lysine concentration as needed (13 g Lys/kg diet). ${ }^{2}$ Provided (per kilogram of diet): vitamin A, 5000 IU; vitamin D3, 1000 IU; vitamin E, 30 IU; thiamine, $2.6 \mathrm{mg}$; riboflavin, $4.8 \mathrm{mg}$; vitamin $\mathrm{B} 6,3.2 \mathrm{mg}$; vitamin $\mathrm{B} 12,20 \mu \mathrm{g}$; vitamin $\mathrm{K} 3,3 \mathrm{mg}$; capantothenate, $10 \mathrm{mg}$; nicotinic acid, $50 \mathrm{mg}$; folic acid, $0.9 \mathrm{mg}$; biotin, $100 \mu \mathrm{g}$; choline chloride, $1000 \mathrm{mg}$; $\mathrm{Mn}, 120 \mathrm{mg}$ (source: $\mathrm{MnO}$ ); $\mathrm{Zn}$, $70 \mathrm{mg}(\mathrm{ZnO}) ; \mathrm{Fe}, 50 \mathrm{mg}\left(\mathrm{FeSO}_{4}\right) ; \mathrm{Cu}, 15 \mathrm{mg}$ (copper sulfate pentahydrate); I, $1.4 \mathrm{mg}$ (Ca-iodate-hexahydrate); Se, $0.28 \mathrm{mg}\left(\mathrm{Na}_{2} \mathrm{SeO}_{3}\right) ; \mathrm{Co}, 0.17 \mathrm{mg}$ [basic cobalt (II) carbonate monohydrate], and butylated hydroxytoluene, $100 \mathrm{mg}$. ${ }^{3} \mathrm{ZY}$ Phytase 5.000, activity per g: 5000 FYT 6-phytase. ${ }^{4} \mathrm{ZY} 68$, activity per g: 1000 FXU Endo-1,4- $\beta$-xylanase.

with and without oxidation step for quantitative determination of the sulphur-containing AAs Met + Cys. The ether extract was analyzed following HCl-hydrolysis of the feed samples.

For body analyses birds were carefully defrosted, autoclaved for $4 \mathrm{~h}$ at $110^{\circ} \mathrm{C}$ (HMC Europe, $\mathrm{GmbH}$, Germany) and homogenized. Subsequently, representative samples were taken for DM and N analyses (Tru-Mac, LECO, Moenchengladbach, Germany).

\subsection{Growth and Feed Efficiency Parameters}

Parameters of the conducted growth study were mean initial BW (IBW), final BW 
Table 2. Analyzed nutrient content of the experimental diets (\% of dry matter, DM) ${ }^{1}$.

\begin{tabular}{cccccc}
\hline \multirow{2}{*}{ Nutrients $^{1}$} & \multicolumn{5}{c}{ Diets } \\
\cline { 2 - 6 } & L1 & L2 & L3 & L4 & L5 \\
\hline Crude protein & 24.6 & 24.3 & 24.7 & 24.7 & 24.7 \\
Ether extract & 5.4 & 5.3 & 5.1 & 4.8 & 4.7 \\
Crude fibre & 1.6 & 1.6 & 1.5 & 1.5 & 1.5 \\
Crude ash & 5.4 & 5.3 & 5.3 & 5.4 & 5.2 \\
N-free extract & 62.8 & 63.3 & 63.3 & 63.5 & 63.7 \\
Starch & 56.6 & 56.9 & 57.3 & 57.4 & 57.6 \\
Sugar & 1.5 & 1.7 & 1.4 & 1.4 & 1.2 \\
ME (MJ/kg DM) & 14.0 & 14.0 & 14.1 & 14.1 & 14.1 \\
Lysine & 1.14 & 1.25 & 1.36 & 1.46 & 1.57 \\
Methionine + Cystine & 1.05 & 1.05 & 1.05 & 1.05 & 1.06 \\
Threonine & 0.93 & 0.93 & 0.93 & 0.93 & 0.93 \\
Tryptophan & 0.24 & 0.24 & 0.24 & 0.24 & 0.24 \\
\hline
\end{tabular}

${ }^{1}$ All samples were analyzed at least as duplicate, values were averaged afterward. ${ }^{2}$ Calculated according to equation of WPSA [38].

(FBW), BW gain (BWG), total feed intake (FI) and feed conversion ratio (FCR). Average daily $\mathrm{N}$ deposition (ND) was calculated as analyzed final body $\mathrm{N}$ mass minus initial body $\mathrm{N}$ mass divided by 21 experimental days. The Lys requirement data were estimated from achieved daily ND depending on dietary Lys concentration or appropriate daily Lys intakes based on nonlinear regression analyses.

\subsection{Model Applications}

According to Schutte and Pack [5], the exponential response curves depending on the graded dietary Lys levels were fitted to experimental data points using the following equation:

$$
y=a+b\left[1-e^{-c(x-d)}\right]
$$

where: $y$ is the daily $\mathrm{N}$ deposition $\left(\mathrm{mg} / \mathrm{BW}_{\mathrm{kg}}^{0.67}\right)$, $a$ is the intercept, $b$ is the maximum daily $\mathrm{N}$ deposition $\left(\mathrm{mg} / \mathrm{BW}_{\mathrm{kg}}^{0.67}\right.$ ) as response from added Lys level, $e$ is the basic number of natural logarithm, $c$ is the slope of the exponential curve, $x$ is the dietary Lys concentration (\% of $\mathrm{DM}$ ) or daily Lys intake $\left(\mathrm{mg} / \mathrm{BW}_{\mathrm{kg}}^{0.67}\right), d$ is the Lys level of the basal diet (\% of $\mathrm{DM}$ or $\mathrm{mg} / \mathrm{BW}_{\mathrm{kg}}^{0.67}$ ), respectively.

The Lys requirement is defined as abscissa value corresponding to the point of the fitted response curve at $95 \%$ of the upper asymptote [1] [5] as maximum daily $\mathrm{N}$ deposition level.

According to several studies [10] [15]-[26] [31] [32] the "Goettingen approach" was applied as follows:

$$
\begin{gathered}
N R=N R_{\max } T\left(1-e^{-b \cdot N I}\right) \\
N D=N R-N M R \\
b=\left[\ln N R_{\max } T-\ln \left(N R_{\max } T-N R\right)\right] / N I
\end{gathered}
$$

where: $N R$ is daily $\mathrm{N}$ retention $\left(\mathrm{mg} / \mathrm{BW}_{\mathrm{kg}}^{0.67}\right), N R_{\max } T$ is theoretical maximum for daily 
$\mathrm{N}$ retention $\left(\mathrm{mg} / \mathrm{BW}_{\mathrm{kg}}^{0.67}\right)$, e is the basic number of natural logarithm (In), $b$ is slope of the $\mathrm{N}$ retention curve (indicating the feed protein quality independent on $\mathrm{N}$ intake), $N I$ is daily $\mathrm{N}$ intake $\left(\mathrm{mg} / \mathrm{BW}_{\mathrm{kg}}^{0.67}\right), N D$ is daily $\mathrm{N}$ deposition $\left(\mathrm{mg} / \mathrm{BW}_{\mathrm{kg}}^{0.67}\right)$, and $N M R$ is daily $\mathrm{N}$ maintenance requirement $\left(\mathrm{mg} / \mathrm{BW}_{\mathrm{kg}}^{0.67}\right)$.

Lys requirement data were calculated based on Equation (5):

$$
L A A I=\left[I n N R_{\max } T-\ln \left(N R_{\max } T-N R\right)\right] / 16 \cdot b c^{-1}
$$

where: $L A A I$ is daily intake of limiting amino acid $\left(\mathrm{mg} / \mathrm{BW}_{\mathrm{kg}}^{0.67}\right), N R_{\max } T$ is theoretical maximum for daily $\mathrm{N}$-retention $\left(\mathrm{mg} / \mathrm{BW}_{\mathrm{kg}}^{0.67}\right), N R$ is daily $\mathrm{N}$-retention $\left(\mathrm{mg} / \mathrm{BW}_{\mathrm{kg}}^{0.67}\right)$, $b$ is slope of the $\mathrm{N}$ retention curve (indicating the feed protein quality independent on $\mathrm{N}$ intake), $c$ is concentration of the first limiting AA (LAA) in the feed protein (g/16g $\mathrm{N}), b c^{-1}$ is the slope of the linear function between $c$ and $b$, expressing the observed dietary LAA efficiency.

Model parameters $N M R\left(113 \mathrm{mg} / \mathrm{BW}_{\mathrm{kg}}^{0.67}\right)$ and $N D_{\max } T\left(4593 \mathrm{mg} / \mathrm{BW}_{\mathrm{kg}}^{0.67}\right)$ for starter chickens (Ross 308) were applied as reported by Pastor et al. [21]. These basic model parameters were utilized for assessing the dietary Lys efficiency $\left(b c_{L y s}^{-1}\right)$ and further modelling of Lys requirement data (Table 5). Therefore, an average of the model parameter $b c_{\text {Lys }}^{-1}\left(34.6 \times 10^{-6}\right)$ as derived from diets L1 to L3 was applied for further modelling of Lys requirement data by the "Goettingen approach".

\subsection{Statistical Analyses}

Results are presented as mean values \pm standard error of the mean $( \pm$ SEM). Statistical analyses run with the SPSS software package program (version 19.0 for Windows, IBM SPSS Statistics Inc., Chicago, IL, USA). Differences between variables were compared by one-way analysis of variance (ANOVA). Verification of variance homogeneity and identification of statistical significance was applied by Tukey and Games-Howell tests. Observed differences between variables with $p \leq 0.05$ were considered to be statistically significant. Individual outlier data $(p \leq 0.05)$ were identified according to Dixon and Massey [41].

\section{Results and Discussion}

\subsection{Growth and Feed Efficiency Parameters}

Summarized results of the growth study are presented in Table 3. Feeding birds with graded levels of dietary Lys yielded significant effects $(p<0.05)$ for FBW, BWG and FI. FCR only tended to be different between treatments. Birds fed the diets with Lys supply below 95\% (L1 and L2) of the expected requirement level (13 g Lys/kg diet as fed) responded with reduced FBW, BWG and FI, respectively. These observations were regardless of limited number of utilized experimental birds in accordance with numerous results reported in the literature [26]. Calculated growth and feed efficiency parameters were enhanced when dietary Lys reached and exceeded the requirement (Diets L3-L5).

\subsection{Parameters of Protein and Lysine Utilization}

According to numerous studies [17] [18] [21] [22] [25] [26], dietary Lys concentration below the required optimum (diets L1 and L2) resulted in significantly decreased daily 
Table 3. Summarized results of growth study of male chickens (Ross 308) with graded levels of Lys in the diet (experimental period 21 days) ${ }^{1}$.

\begin{tabular}{ccccccc}
\hline & \multicolumn{5}{c}{ Diet $^{2}$} \\
\cline { 2 - 6 } Parameter & $\mathrm{L} 1$ & $\mathrm{~L} 2$ & $\mathrm{~L} 3$ & $\mathrm{~L} 4$ \\
$(80 \%)$ & $(87.5 \%)$ & $(95 \%)$ & $(102.5)$ & $\begin{array}{c}\mathrm{L} 5 \\
(110 \%)\end{array}$ \\
& $44.8^{\mathrm{a}} \pm 0.3$ & $43.9^{\mathrm{a}} \pm 0.2$ & $44.4^{\mathrm{a}} \pm 0.5$ & $44.1^{\mathrm{a}} \pm 0.2$ & $45.9^{\mathrm{a}} \pm 0.2$ & 0.142 \\
\hline $\mathrm{IBW}^{3}(\mathrm{~g})$ & $624.9^{\mathrm{c}} \pm 29$ & $918.5^{\mathrm{b}} \pm 21$ & $1159.0^{\mathrm{a}} \pm 15$ & $1120.3^{\mathrm{a}} \pm 12$ & $1103.4^{\mathrm{a}} \pm 49$ & 0.000 \\
$\mathrm{FBW}^{4}(\mathrm{~g})$ & $580.1^{\mathrm{c}} \pm 29$ & $874.65^{\mathrm{b}} \pm 21$ & $1114.45 \mathrm{a}^{\mathrm{a}} \pm 15$ & $1076.23^{\mathrm{a}} \pm 12$ & $1057.54^{\mathrm{a}} \pm 49$ & 0.000 \\
$\mathrm{BWG}^{5}(\mathrm{~g})$ & $729.4^{\mathrm{c}} \pm 18$ & $1028.8^{\mathrm{b}} \pm 29$ & $1335.9^{\mathrm{a}} \pm 13$ & $1249.5^{\mathrm{a}} \pm 5$ & $1235.4^{\mathrm{a}} \pm 50$ & 0.000 \\
$\mathrm{FI}^{6}(\mathrm{~g})$ & $1.26^{\mathrm{a}} \pm 0.03$ & $1.23^{\mathrm{a}} \pm 0.00$ & $1.20^{\mathrm{a}} \pm 0.02$ & $1.16^{\mathrm{a}} \pm 0.01$ & $1.17^{\mathrm{a}} \pm 0.01$ & 0.186 \\
$\mathrm{FCR}^{7}$ & & & &
\end{tabular}

${ }^{1}$ Mean values (three replicates \pm SEM) with similar superscripts within rows are not significantly different $(p>0.05)$. ${ }^{2} \mathrm{~L} 1=80 \%, \mathrm{~L} 2=87.5 \%, \mathrm{~L} 3=95 \%, \mathrm{~L} 4=102.5 \%, \mathrm{~L} 5=110 \%$ of the expected dietary lysine concentration as needed $(13$ g Lys/kg diet). ${ }^{3}$ Initial body weight. ${ }^{4}$ Final body weight. ${ }^{5}$ Body weight gain (FBW-IBW). ${ }^{6}$ Feed intake (total FI during $21 \mathrm{~d}) .{ }^{7}$ Feed conversion ratio (total FI (g): BWG (g)).

protein deposition (PD) as demonstrated in Table 4. The derived model parameter $b$ as measure of the feed protein quality was significantly increased by gradually elevated Lys concentration up to the requirement level. In line with results of Pastor et al. [21] and Khan et al. [25], the parameter $b c_{L y s}^{-1}$ as expression of the dietary Lys efficiency was not significantly different $(p>0.05)$ within the limiting range of Lys. The decline of $b c_{L y s}^{-1}$ was initiated with diet L4 corresponding to an oversupply of Lys in the experimental diets $\mathrm{L} 4$ and $\mathrm{L} 5$, respectively.

\subsection{Lysine Requirement Estimation by Supplementation Technique}

The results of daily ND ( $\left.\mathrm{mg} / \mathrm{BW}_{\mathrm{kg}}^{0.67}\right)$ as fitted by exponential function depending on graded dietary Lys levels (\% of DM) according to Equation (1) for male fast growing chickens during starter period (1-21d) are shown in Figure 1. The point at $95 \%$ of the upper asymptote yields $1.43 \%$ Lys in DM or $1.30 \%$ Lys in the diet as fed as requirement corresponding to $1974 \mathrm{mg} / \mathrm{BW}_{\mathrm{kg}}^{0.67}$ daily ND. Making use of $90 \%$ of the asymptote $\left(\mathrm{ND}=1947 \mathrm{mg} / \mathrm{BW}_{\mathrm{kg}}^{0.67} / \mathrm{d}\right)$ and ranking within the confidence area $( \pm 5 \%)$ of the exponential curve yields $1.36 \%$ Lys in DM and $1.24 \%$ in the diet as fed, respectively.

It has to be noted that this type of requirement estimates based on an arbitrary graduation to make use of the maximum ND response without considering the real feed intake as factor of influence [10] [26] may yield results in question.

In consequence, the observed individual ND data were fitted depending on averaged Lys intake levels of each experimental diet (Figure 2). At 95\% of the asymptote 1255 $\mathrm{mg} / \mathrm{BW}_{\mathrm{kg}}^{0.67}$ Lys are needed for $2003 \mathrm{mg} / \mathrm{BW}_{\mathrm{kg}}^{0.67}$ daily ND. Otherwise, at $90 \%$ of the asymptote $\left(\mathrm{ND}=1975 \mathrm{mg} / \mathrm{BW}_{\mathrm{kg}}^{0.67} / \mathrm{d}\right), 1138 \mathrm{mg}$ Lys $/ \mathrm{BW}_{\mathrm{kg}}^{0.67}$ per day are required. Based on the observed average of BW (540 g) and daily FI (60 g/d) with diets L3-L5, Lys requirement data of $830 \mathrm{vs.} 753 \mathrm{mg} / \mathrm{d}$ or $1.38 \%$ vs. $1.26 \%$ of the diet as fed are derived.

Furthermore, if observed ND data were fitted as function of real individual Lys intakes (Figure 3), at $95 \%$ of the asymptote $\left(2023 \mathrm{mg} \mathrm{ND} / \mathrm{BW}_{\mathrm{kg}}^{0.67} / \mathrm{d} ; 1320 \mathrm{mg}\right.$ Lys $/ \mathrm{BW}_{\mathrm{kg}}^{0.67} / \mathrm{d}$ ) the Lys requirement estimates were $874 \mathrm{mg} / \mathrm{d}$ or $1.46 \%$ of the diet for equal zoo-technical data. The corresponding data at $90 \%$ of the asymptote were $785 \mathrm{mg}$ Lys/d or $1.31 \%$ Lys in the diet as fed. This example of calculation demonstrates the 
Table 4. Summarized results of average crude protein deposition (PD), protein quality and Lys efficiency depending on graded dietary Lys supply (experimental period 21 days) ${ }^{1}$.

\begin{tabular}{|c|c|c|c|c|c|c|}
\hline \multirow[b]{2}{*}{ Parameter } & \multicolumn{5}{|c|}{$\operatorname{Diet}^{2}$} & \multirow[b]{2}{*}{$p$} \\
\hline & $\begin{array}{c}\mathrm{L} 1 \\
(80 \%)\end{array}$ & $\begin{array}{c}\text { L2 } \\
(87.5 \%)\end{array}$ & $\begin{array}{c}\text { L3 } \\
(95 \%)\end{array}$ & $\begin{array}{c}\text { L4 } \\
(102.5 \%)\end{array}$ & $\begin{array}{c}\text { L5 } \\
(110 \%)\end{array}$ & \\
\hline $\begin{array}{l}\text { PD } \\
(\mathrm{g} / \mathrm{d})\end{array}$ & $4.42^{c} \pm 0.22$ & $6.84^{\mathrm{b}} \pm 0.17$ & $8.43^{\mathrm{a}} \pm 0.12$ & $8.90^{\mathrm{a}} \pm 0.10$ & $8.69^{a} \pm 0.39$ & 0.000 \\
\hline Protein quality $(b)^{3}$ & $158^{\mathrm{b}} \pm 4.6$ & $182^{\mathrm{a}} \pm 0.9$ & $186^{\mathrm{a}} \pm 2.9$ & $193^{\mathrm{a}} \pm 2.6$ & $188^{\mathrm{a}} \pm 2.3$ & 0.004 \\
\hline Lys efficiency $\left(b c^{-1}\right)^{4}$ & $34.2^{\mathrm{a}} \pm 1.0$ & $35.6^{\mathrm{a}} \pm 0.2$ & $33.9^{\mathrm{a}} \pm 0.5$ & $32.5^{\mathrm{ab}} \pm 0.4$ & $29.5^{\mathrm{b}} \pm 0.4$ & 0.009 \\
\hline
\end{tabular}

${ }^{1}$ Mean values (three replicates \pm SEM) with similar superscripts within rows are not significantly different $(p>0.05)$. ${ }^{2} \mathrm{~L} 1=80 \%, \mathrm{~L} 2=87.5 \%, \mathrm{~L} 3=95 \%, \mathrm{~L} 4=102.5 \%, \mathrm{~L} 5=110 \%$ of the expected dietary Lys concentration as needed $(13 \mathrm{~g}$ Lys $/ \mathrm{kg}$ diet). ${ }^{3} b=$ Model parameter assessing the dietary protein quality $\left(b \times 10^{6}\right) \cdot{ }^{4} b c^{-1}=$ Model parameter assessing the dietary efficiency of the limiting AA Lys $\left(b c_{L y s}^{-1} \times 10^{6}\right)$.

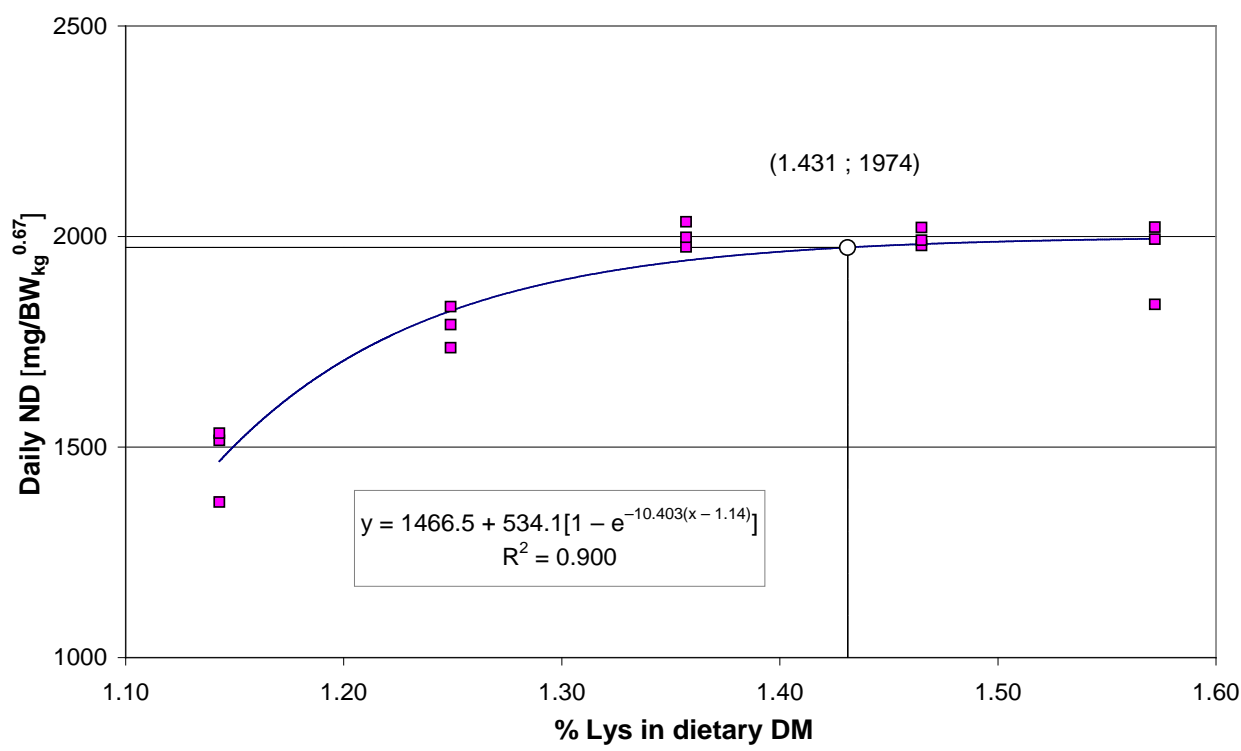

Figure 1. Fitted exponential plot of daily $\mathrm{N}$ deposition (ND) per metabolic body weight $\left(\mathrm{BW}_{\mathrm{kg}}^{0.67}\right)$ as function of graded dietary Lys levels (\% of dry matter, DM) for male fast growing chicken. Calculated optimum data at $95 \%$ of the asymptote (-०-) are based on experimental data with three replications per diet during the growth study of $21 \mathrm{~d}$.

importance of methodical standardization for valid conclusions in AA requirement studies.

\subsection{Lysine Requirement Estimation by "Goettingen Approach"}

The summarized results of modelling Lys requirement data according to Equation (5) for graded daily PD resp. BWG responses and predicted FI levels are presented in Table 5. The graded PD values were based on results (diets L3 - L5) of the current growth study during the first three weeks post-hatching. According to the model calculation, for average performance of 8 to $9 \mathrm{~g}$ daily PD between 680 and $800 \mathrm{mg}$ Lys per bird and day are required. Expressed as percent of the starter diet, dependent on BWG and graded FI (60, 70 and $80 \mathrm{~g} / \mathrm{d}$ ) a high variation between $1.0 \%$ and $1.6 \%$ Lys is observed. This underlines the importance of real feed intake data for valid conclusions about the 


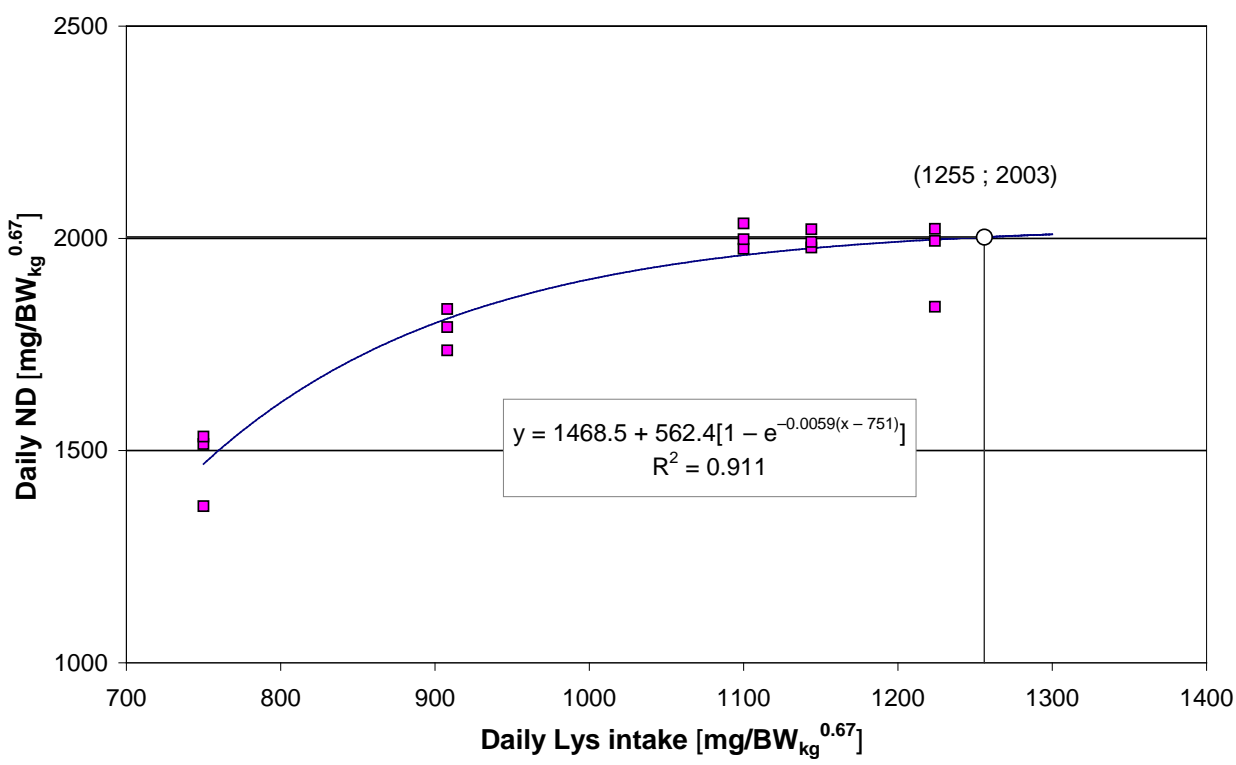

Figure 2. Fitted exponential plot of daily $\mathrm{N}$ deposition (ND) per metabolic body weight $\left(\mathrm{BW}_{\mathrm{kg}}^{0.67}\right)$ as function of averaged daily Lys intake in male fast growing chicken. Calculated optimum data at $95 \%$ of the asymptote (-०-) are based on experimental data with three replications per diet during the growth study of $21 \mathrm{~d}$.

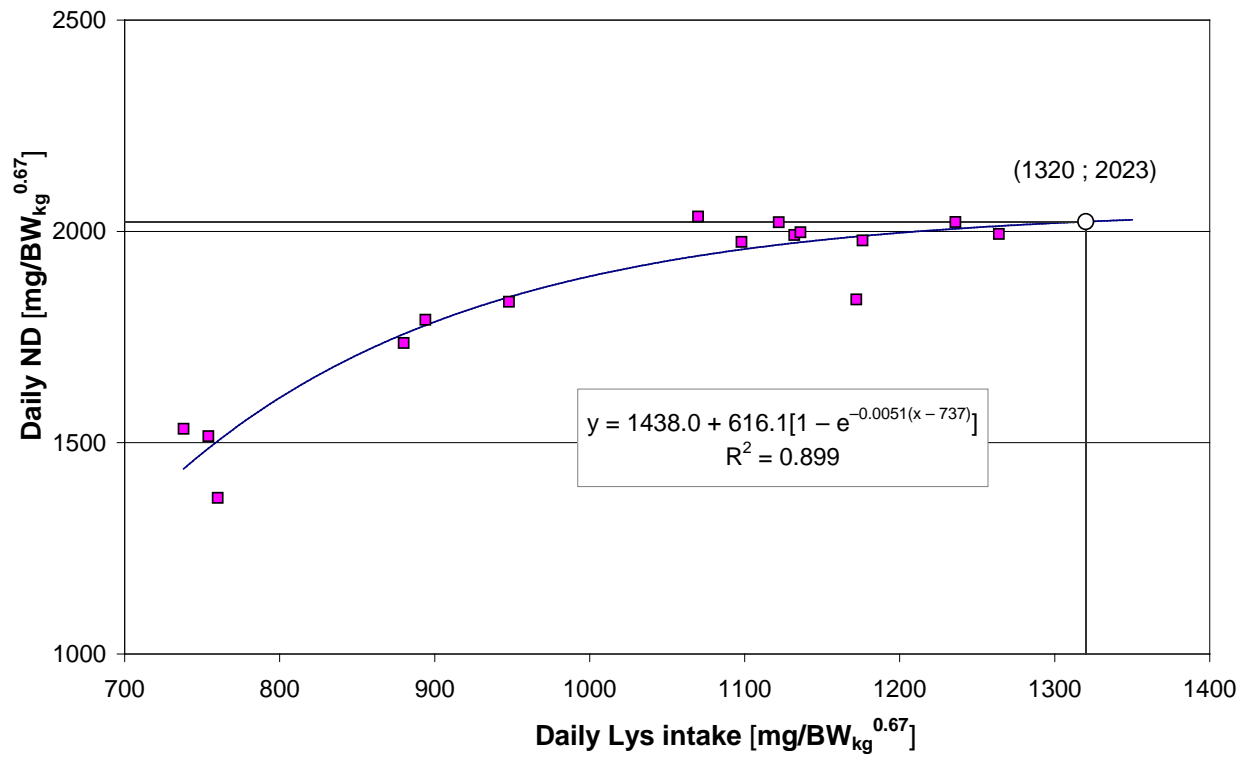

Figure 3. Fitted exponential plot of daily $\mathrm{N}$ deposition (ND) per metabolic $\mathrm{BW}\left(\mathrm{BW}_{\mathrm{kg}}^{0.67}\right)$ as function of observed daily Lys intake in male fast growing chicken. Calculated optimum data at 95\% of the asymptote (-०-) are based on experimental data with three replications per diet during the growth study of $21 \mathrm{~d}$.

adequate dietary AA concentration.

In consequence, a high variation of Lys requirement estimates also can be found in the literature [26]. It is well documented that derived AA requirement of growing chickens depend on many animal and environment factors which have to be considered for valid recommendations. Especially, diet composition regarding the feed ingredients, 
Table 5. Model calculation of the daily Lys requirement for male fast growing chickens depending on assumed performance data and predicted daily feed intake (Mean $\mathrm{BW}^{1}=540 \mathrm{~g}$; dietary Lys efficiency $\left.{ }^{2}=34.6\right)$.

\begin{tabular}{cccccccc}
\hline BWG & PD & ND & \multicolumn{2}{c}{ Lys requirement } & \multicolumn{3}{c}{$\begin{array}{c}\text { Optimal } \begin{array}{c}\text { Lys content in the starter diet } \\
(\%)\end{array} \\
\text { at feed intake of }\end{array}$} \\
\hline$(\mathrm{g} / \mathrm{d})$ & $(\mathrm{g} / \mathrm{d})$ & $\left(\mathrm{mg} / \mathrm{BW}_{\mathrm{kg}}^{0.67}\right)$ & $\left(\mathrm{mg} / \mathrm{BW}_{\mathrm{kg}}^{0.67}\right)$ & $(\mathrm{mg} / \mathrm{d})$ & $50 \mathrm{~g} / \mathrm{d}$ & $60 \mathrm{~g} / \mathrm{d}$ & $70 \mathrm{~g} / \mathrm{d}$ \\
\hline 48.5 & 8.0 & 1932 & 1030 & 682 & 1.36 & 1.14 & 0.98 \\
49.1 & 8.1 & 1956 & 1046 & 693 & 1.39 & 1.16 & 0.99 \\
49.7 & 8.2 & 1980 & 1063 & 704 & 1.41 & 1.17 & 1.01 \\
50.3 & 8.3 & 2004 & 1080 & 715 & 1.43 & 1.19 & 1.02 \\
50.9 & 8.4 & 2028 & 1097 & 727 & 1.45 & 1.21 & 1.04 \\
51.5 & 8.5 & 2053 & 1114 & 738 & 1.48 & 1.23 & 1.05 \\
52.1 & 8.6 & 2077 & 1131 & 749 & 1.50 & 1.25 & 1.07 \\
52.7 & 8.7 & 2101 & 1148 & 761 & 1.52 & 1.27 & 1.09 \\
53.3 & 8.8 & 2125 & 1166 & 772 & 1.54 & 1.29 & 1.10 \\
53.9 & 8.9 & 2149 & 1184 & 784 & 1.57 & 1.31 & 1.12 \\
54.5 & 9.0 & 2173 & 1202 & 796 & 1.59 & 1.33 & 1.14 \\
\hline
\end{tabular}

${ }^{1}$ Measured mean body weight of birds during the experimental period of 21 days fed diets L3 to L5 according to data of Table 3. ${ }^{2}$ Observed average dietary Lys efficiency $\left(b c_{l y s}^{-1} \times 10^{6}\right)$ of experimental diets L1-L3 according to data in Table 4. BWG = Body weight gain (at supposed crude protein content of $16.5 \%$ in BWG), PD = Protein deposition, $\mathrm{ND}=\mathrm{N}$ deposition

dietary protein concentration and AA balance as well as factors of AA bioavailability as affected by anti-nutritional factors may act as important factors of influence. In addition, according to the selected response criteria (performance characteristics, feed efficiency data, physiological parameters) varying requirement data are observed. Furthermore, the applied statistical models for assessing AA requirements (broken-line models, non-linear regression analyses, response surface methods, empirical approaches, etc.) considerably impact on validity of concluded AA requirement data [4] [9] [11] [42]-[49].

Possibilities and limitations of different procedures for AA requirement studies were already discussed elsewhere [12] [50]. Still a controversy exists according to the procedures which are mostly adapted to the physiological conditions in the animal. Generally, the choice of a model to evaluate experimental data from growth or $\mathrm{N}$ balance trials should depend on the objectives of the experiment [51]. Strongly required is a physiological interpretation of the response dependent on nutrient intake, especially on the yielded protein deposition of growing animals. From practical point of view, linear (broken-line) or quadratic functions have the advantage that they offer a definite breakpoint of the curve which can be interpreted as "requirement" level. In contrast, fitting of experimental data by an exponential function does not yield a fixed breakpoint as "requirement" and the subjective choice of a point below the achieved asymptote is more or less arbitrary.

The applied "Goettingen approach" makes use of an exponential function and describes the physiological process of $\mathrm{N}$ utilization in growing animals depending on $\mathrm{N}$ intake or LAA intake. The modelling procedure involves both the BW and graded performance data $(\mathrm{PD}, \mathrm{BWG})$ as reference criteria for estimating of growth dependent $\mathrm{AA}$ 
requirement data. Additionally, graded data of dietary Lys efficiency and predicted feed intake data can be taken into account for a wide scale of requirement data corresponding to the most important factors of influence. Consequently, remarkable modulation of the derived optimal dietary Lys concentration for modern meat-type chickens is not surprising (Table 5).

\section{Conclusions}

The presented modelling of Lys requirement based on data evaluation by "Goettingen approach" is demonstrating that an adequate dietary Lys supply to yield optimal performance data and feed efficiency in broiler chicken production is modulated by different animal factors like age period, aimed growth (PD) performance and the realized FI. In addition, dietary factors influencing the Lys efficiency need more consideration. The observed high variation of Lys recommendations in meat type chicken is partly subjected to this important factor and requires more investigations, but also more standardized experimental conditions for more validated conclusions.

Generally, a fine structured network of recommendations could be achieved by modelling of requirement data which are adequate for integration into feeding systems continuously adapted to changes in BW, growth, FI and in-feed Lys requirements. However, more reliable data due to the expected variation of AA efficiency in feed ingredients are needed. By this way, application of physiologically based new procedures like "Goettingen approach" might contribute to more validated recommendations in the future and to reduce the currently observed high variation in Lys requirement data.

\section{Acknowledgements}

The authors thank German Academic Exchange Service (DAAD) and Experts4Asia program for financial support of travel and living expenses of Samadi.

\section{References}

[1] Robbins, K.R., Norton, H.W. and Baker, D.H. (1979) Estimation of Nutrient Requirements from Growth Data. The Journal of Nutrition, 109, 1710-1714.

[2] Ware, G.O., Phillips, R.D., Parrish, R.S. and Moon, L.C. (1980) A Comparison of Two Nonlinear Models for Describing Intake-Response Relationships in Higher Organisms. The Journal of Nutrition, 110, 765-770.

[3] Mercer, L.P. (1992) The Determination of Nutritional Requirements: Mathematical Modeling of Nutrient-Response Curves. The Journal of Nutrition, 122, 706-708.

[4] Barbour, G., Latshaw, J.D. and Bishop, B. (1993) Lysine Requirement of Broiler Chicks as Affected by Protein Source and Method of Statistical Evaluation. British Poultry Science, 34, 747-756. https://doi.org/10.1080/00071669308417633

[5] Schutte, J.B. and Pack, M. (1995) Sulfur Amino Acid Requirement of Broiler Chicks from Fourteen to Thirty-Eight Days of Age. 1. Performance and Carcass Yield. Poultry Science, 74, 480-487. https://doi.org/10.3382/ps.0740480

[6] Remmenga, M.D., Milliken, G.A., Kratzer, D., Schwenke, J.R. and Rolka, H.R. (1997) Estimating the Maximum Effective Dose in a Quantitative Dose-Response Experiment. Journal of Animal Science, 75, 2174-2183. https://doi.org/10.2527/1997.7582174x

[7] Vedenov, D. and Pesti G.M. (2008) A Comparison of Methods of Fitting Several Models to Nutritional Response Data. Journal of Animal Science, 86, 500-507. 
https://doi.org/10.2527/jas.2007-0536

[8] Pesti, G.M., Vedenov, D., Cason, J.A. and Billard, L. (2009) A Comparison of Methods to Estimate Nutritional Requirements from Experimental Data. British Poultry Science, 50, 16-32. https://doi.org/10.1080/00071660802530639

[9] Mehri, M. (2014) Optimization of Response Surface and Neural Network Models in Conjugation with Desirability Function for Estimation of Nutritional Needs of Methionine, Lysine, and Threonine in Broiler Chickens. Poultry Science, 93, 1862-1867. https://doi.org/10.3382/ps.2013-03689

[10] Liebert, F. (2015) Basics and Applications of an Exponential Nitrogen Utilization Model (“Goettingen Approach") for Assessing Amino Acid Requirements in Growing Pigs and Meat Type Chickens Based on Dietary Amino Acid Efficiency. In: Sakomura, N.K., Gous, R., Kyriazakis, I. and Hauschild, L., Eds., Nutritional Modelling for Pigs and Poultry, CABI Publishing, Wallingford, Oxfordshire, UK, 73-87.

https://doi.org/10.1079/9781780644110.0073

[11] Baker, D.H., Batal, A.B., Parr, T.M., Augspurger, N.R. and Parsons C.M. (2002) Ideal Ratio (Relative ro Lysine) of Tryptophan, Threonine, Isoleucine, and Valine for Chicks during the Second and Third Weeks Posthatch. Poultry Science, 81, 485-494.

https://doi.org/10.1093/ps/81.4.485

[12] Baker, D.H. (2003) Ideal Amino Acid Patterns for Broiler Chicks. In: D’Mello, J.P.F., Ed., Amino Acids in Animal Nutrition, 2nd Edition, CAB International, Wallingford, 223-235. https://doi.org/10.1079/9780851996547.0223

[13] Wang, T.C. and Fuller, M.F. (1989) The Optimum Dietary Amino Acid Pattern for Growing Pigs. 1. Experiments by Amino Acid Deletion. British Journal of Nutrition, 62, 77-89. https://doi.org/10.1079/BJN19890009

[14] Gebhardt, G. (1966) Die Bewertung der Eiweißqualität von Nahrungs-und Futtermitteln mit Hilfe des N-Bilanzversuches. In: Hock, A., Ed., Vergleichende Ernährungslehre des Menschen und seiner Haustiere, Gustav Fischer Verlag, Jena, 323-348.

[15] Samadi and Liebert, F. (2006a) Estimation of Nitrogen Maintenance Requirements and Potential for Nitrogen Deposition in Fast-Growing Chickens Depending on Age and Sex. Poultry Science, 85, 1421-1429. https://doi.org/10.1093/ps/85.8.1421

[16] Samadi and Liebert, F. (2006b) Modeling Threonine Requirement Depending on Age, Protein Deposition, Dietary Threonine Efficiency and Sex of Fast Growing Chickens. Poultry Science, 85, 1961-1968. https://doi.org/10.1093/ps/85.11.1961

[17] Samadi and Liebert, F. (2007a) Lysine Requirement of Fast Growing Chickens-Effect of Age, Sex, Level of Protein Deposition and Dietary Lysine Efficiency. The Journal of Poultry Science, 44, 63-72. https://doi.org/10.2141/jpsa.44.63

[18] Samadi and Liebert, F. (2007b) Threonine Requirement of Slow Growing Male Chickens Depends on Age and Dietary Efficiency of Threonine Utilization. Poultry Science, 86, 11401148. https://doi.org/10.1093/ps/86.6.1140

[19] Samadi and Liebert, F. (2008) Modelling the Optimal Lysine to Threonine Ratio in Growing Chickens Depending on Age and Efficiency of Dietary Amino Acid Utilization. British Poultry Science, 49, 45-54. https://doi.org/10.1080/00071660701821667

[20] Liebert, F. (2008) Modelling of Protein Metabolism Yields Amino Acid Requirements Dependent on Dietary Amino Acid Efficiency, Growth Response, Genotype and Age of Growing Chicken. Avian Biology Research, 1, 101-110. https://doi.org/10.3184/175815508X388074

[21] Pastor, A., Wecke, C. and Liebert, F. (2013) Assessing the Age-Dependent Optimal Dietary Branched-Chain Amino Acid Ratio in Growing Chicken by Application of a Nonlinear Modeling Procedure. Poultry Science, 92, 3184-3195. https://doi.org/10.3382/ps.2013-03340

[22] Wecke, C. and Liebert, F. (2013) Improving the Reliability of Optimal In-Feed Amino Acid 
Ratios Based on Individual Amino Acid Efficiency Data from N Balance Studies in Growing Chicken. Animals, 3, 558-573. https://doi.org/10.3390/ani3030558

[23] Khan, D.R., Wecke, C., Sharifi, A.R. and Liebert, F. (2015a) Evaluating the Age Dependent Potential for Protein Deposition in Naked Neck Meat Type Chicken. Animals, 5, 56-70. https://doi.org/10.3390/ani5010056

[24] Khan, D.R., Wecke, C. and Liebert, F. (2015b) Does the Naked Neck Meat Type Chicken Yield Lower Methionine Requirement Data? Animals, 5, 151-160. https://doi.org/10.3390/ani5020151

[25] Khan, D.R., Wecke, C. and Liebert, F. (2015c) An Elevated Dietary Cystine to Methionine Ratio Does Not Impact on Dietary Methionine Efficiency and the Derived Optimal Methionine to Lysine Ratio in Diets for Meat Type Chicken. Open Journal of Animal Sciences, 5, 457466. https://doi.org/10.4236/ojas.2015.54047

[26] Wecke, C., Pastor, A. and Liebert, F. (2016) Validation of the Lysine Requirement as Reference Amino Acid for Ideal In-Feed Amino Acid Ratios in Modern Fast Growing MeatType Chickens. Open Journal of Animal Science, 6, 185-194. https://doi.org/10.4236/ojas.2016.63024

[27] Thong, H.T. and Liebert, F. (2004a) Potential for Protein Deposition and Threonine Requirement of Modern Genotype Borrows Fed Graded Levels of Protein with Threonine as the Limiting Amino Acid. Journal of Animal Physiology and Animal Nutrition, 88, 196203. https://doi.org/10.1111/j.1439-0396.2004.00457.x

[28] Thong, H.T. and Liebert, F. (2004b) Amino Acid Requirement of Growing Pigs Depending on Amino Acid Efficiency and Level of Protein Deposition. 1st Communication: Lysine. Archives of Animal Nutrition, 58, 69-87. https://doi.org/10.1080/00039420310001656695

[29] Thong, H.T. and Liebert, F. (2004c) Amino Acid Requirement of Growing Pigs Depending on Amino Acid Efficiency and Level of Protein Deposition. 2nd Communication: Threonine. Archives of Animal Nutrition, 58, 157-168. https://doi.org/10.1080/00039420410001667520

[30] Liebert, F. and Wecke, C. (2008) Models for Further Developing the Evaluation of Protein and Amino Acids as Well as for Predicting Performance from Energy and Amino Acids Intake. In: Staudacher, W., Ed., Recommendations for the Supply of Energy and Nutrients to Pigs, DLG-Verlag-GmbH, Frankfurt, 219-230.

[31] Wecke, C. and Liebert, F. (2009) Lysine Requirement Studies in Modern Genotype Barrows Dependent on Age, Protein Deposition and Dietary Lysine Efficiency. Journal of Animal Physiology and Animal Nutrition, 93, 295-304. https://doi.org/10.1111/j.1439-0396.2009.00923.x

[32] Wecke, C. and Liebert, F. (2010) Optimal Dietary Lysine to Threonine Ratio in Pigs (30 $110 \mathrm{~kg} \mathrm{BW)} \mathrm{Derived} \mathrm{from} \mathrm{Observed} \mathrm{Dietary} \mathrm{Amino} \mathrm{Acid} \mathrm{Efficiency.} \mathrm{Journal} \mathrm{of} \mathrm{Animal}$ Physiology and Animal Nutrition, 94, e277-e285. https://doi.org/10.1111/j.1439-0396.2009.00969.x

[33] Liebert, F. and Benkendorff, K. (2007) Modeling Lysine Requirements of Oreochromis niloticus due to Principles of the Diet Dilution Technique. Aquaculture, 267, 100-110. https://doi.org/10.1016/j.aquaculture.2007.02.022

[34] Liebert, F. (2009) Amino Acid Requirement Studies in Oreochromis niloticus by Application of Principles of the Diet Dilution Technique. Journal of Animal Physiology and Animal Nutrition, 93, 787-793. https://doi.org/10.1111/j.1439-0396.2008.00869.x

[35] Fernandez, R.S., Ayogi, S., Han, Y., Parson, C.M. and Baker D.H. (1994) Limiting Order to Amino Acids in Corn and Soybean for Growth of the Chicks. Poultry Science, 73, 18871896. https://doi.org/10.3382/ps.0731887

[36] Kidd, M.T. (2000) Nutritional Considerations Concerning Threonine in Broilers. World $s$ Poultry Science Journal, 56, 139-151. https://doi.org/10.1079/WPS20000011 
[37] Emmert, J.L. and Baker, D.H. (1997) Use of the Ideal Protein Concept for Precision Formulation of Amino Acid Levels in Broiler Diets. The Journal of Applied Poultry Research, 6, 462-470. https://doi.org/10.1093/japr/6.4.462

[38] WPSA (1984) The Prediction of Apparent Metabolizable Energy Values for Poultry in Compound Feeds. World s Poultry Science Journal, 40, 181-182.

[39] NRC (1994) Nutrient Requirements of Poultry. 9th Revised Edition, National Academy Press, Washington DC.

[40] Naumann, C. and Bassler, R. (1997) Die chemische Untersuchung von Futtermitteln. Methodenbuch, Volume III, VDLUFA-Verlag, Darmstadt.

[41] Dixon, W.J, and Massey F.J. (1957) Introduction to Statistical Analysis, 2nd Edition, Mc Graw-Hill Book, New York, 275-280.

[42] Latshaw, J.D. (1993) Dietary Lysine Concentrations from Deficient to Excessive and the Effects on Broiler Chicks. British Poultry Science, 34, 951-958. https://doi.org/10.1080/00071669308417655

[43] Vazquez, M. and Pesti, G.M. (1997) Estimation of the Lysine Requirement of Broiler Chicks for Maximum Body Gain and Feed Efficiency. The Journal of Applied Poultry Research, 6, 241-246. https://doi.org/10.1093/japr/6.3.241

[44] Leclercq, B. (1998) Specific Effects of Lysine on Broiler Production: Comparison with Threonine and Valine. Poultry Science, 77, 118-123. https://doi.org/10.1093/ps/77.1.118

[45] Coon, C. (2004) The Ideal Amino Acid Requirements and Profile for Broilers, Layers, and Broiler Breeders. Technical Information of American Soybean Association, 153, 1-43.

[46] Redshaw, M. (2008) Defining Responses to an Amino Acid. Amino News, 10, 17-24.

[47] Dozier III, W.A., Corzo, A., Kidd, M.T., Tillman, P.B. and Branton, S.L. (2009) Digestible Lysine Requirements of Male and Female Broilers from Fourteen to Twenty-Eight Days of Age. Poultry Science, 88, 1676-1682. https://doi.org/10.3382/ps.2008-00539

[48] Abudabos, A. and Aljumaah, R. (2010) Evaluation of Digestible Lysine Needs for Male Broiler. International Journal of Poultry Science, 9, 1146-1151.

https://doi.org/10.3923/ijps.2010.1146.1151

[49] Ghahri, H., Gaykani, R. and Toloie T. (2010) Effect of Dietary Crude Protein Level on Performance and Lysine Requirements of Male Broiler Chickens. African Journal of Agricultural Research, 5, 1228-1234.

[50] D’Mello, J.P.F. (2003) Responses of Growing Poultry to Amino Acids. In: D’Mello, J.P.F., Ed., Amino Acids in Animal Nutrition, 2nd Edition, CAB International, Wallingford, 237263. https://doi.org/10.1079/9780851996547.0237

[51] Baker, D.H. (1986) Problems and Pitfalls in Animal Experiments Designed to Establish Dietary Requirements for Essential Nutrients. The Journal of Nutrition, 116, 2339-2349. 
Submit or recommend next manuscript to SCIRP and we will provide best service for you:

Accepting pre-submission inquiries through Email, Facebook, LinkedIn, Twitter, etc. A wide selection of journals (inclusive of 9 subjects, more than 200 journals) Providing 24-hour high-quality service

User-friendly online submission system

Fair and swift peer-review system

Efficient typesetting and proofreading procedure

Display of the result of downloads and visits, as well as the number of cited articles Maximum dissemination of your research work

Submit your manuscript at: http://papersubmission.scirp.org/

Or contact ojas@scirp.org 